\title{
Physico-Chemical and Harvest Time Alterations in Pineapple Fruits 'Smooth Cayenne' Caused by Paclobutrazol
}

\author{
Andréa Maria Antunes ${ }^{1}$, Elizabeth Orika Ono ${ }^{1 *}$, Aloísio Costa Sampaio $^{2}$ and João \\ Domingos Rodrigues ${ }^{1}$ \\ ${ }^{1}$ Universidade Estadual Paulista - UNESP; Departamento de Botânica; IB; C.P. 510; 18618-000; Botucatu - São \\ Paulo - Brasil. ${ }^{2}$ Universidade Estadual Paulista - UNESP; Departamento de Ciências Biológicas; FC; C. P. 473; \\ 17033-360; Bauru - São Paulo - Brasil
}

\begin{abstract}
The aim of this work was to assess the effect of an inhibitor acting in the floral differentiation on the physicochemical characteristics of pineapple fruits and on the effect in the harvest time. Paclobutrazol was used at concentrations of 100, 150, and $200 \mathrm{mg} \mathrm{L}^{-1}$, applied 2, 3 or 4 times in 'Smooth Cayenne' pineapple plants. The treatment did not influence the chemical characteristics of the fruits, and even having some physical alterations, they were within the quality standard for the commercialization. The harvest time was amplified in all the treatments

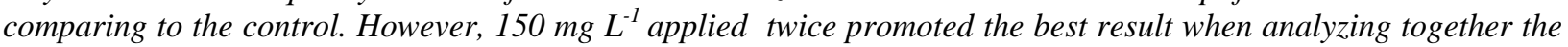
harvest time and the fruit fresh matter.
\end{abstract}

Key words: Ananas comosus, plant growth inhibitor, physico-chemical characteristics, flowering

\section{INTRODUCTION}

The pineapple plant (Ananas comosus (L.) Merril) originated from the South America. They are found disseminated at tropic and subtropic regions, where the Smooth Cayenne cultivar, which is highly productive, with vigorous growth and with fruits of excellent physico-chemical qualities prevails for cropping (Py et al., 1984). However, its natural flowering causes severe problems, making its management difficult due to the disuniformity of the fruits and harvesting dates, which increases the production costs. The commercial cultivation of the pineapple crop results from the fact that florewing in this plant can be controlled using plant growth regulators.
Lately, the most used method to uniform the harvest time is the use of plant growth regulators that allow the artificial induction of floral differentiation. Nevertheless, they generate a harvest concentration from November to January, a period in which the prices are bellow the annual average. Other way to interfere in the natural flowering differentiation process of pineapple plant and have a uniform production, which would be offered during the period of high prices could be the utilization of plant growth (Min and Bartholomew, 1996; Barbosa et al., 1998; Cunha et al., 2003).

The months of highest prices are the ones with the lowest availability of the product in the market. According to Barbosa et al. (1998), the harvest

\footnotetext{
${ }^{*}$ Author for correspondence
} 
concentration in the period from November to January contributes to a fall in the price of the fruit, having as the main cause the natural differentiation of the pineapple fruit that happens from May to June, and the flowering period from July to September, therefore the best prices are between February and May. For the São Paulo State, the largest price stationary indexes were found in February, while the largest offers of the fruit happen from December to January (Agrianual, 2004; Sampaio et al., 1992).

The price variation at this period reveals the importance of a program of pineapple fruit production utilizing techniques such as the use of plant growth regulators, especially for the natural flowering inhibition once only the artificial induction concentrates the production in the months of more offer and lower prices. However, the use of plant growth regulators for interfering in the flowering mechanism might influence the plant growth, fruit development, and their physicochemical characteristics, among others (Cunha et al., 2002). In few studies, the paclobutrazol reduced the fresh matter of fruits in pineapple (Cunha et al., 2002; Barbosa, 1997)).

The influence of triazols in the physiological disorder incidence and quality after fruit harvesting needs more study (Davies et al., 1988). It is known that contents of the solid solubles in cherries and the fruit size were not altered by the action of paclobutrazol (Facteau and Chestnut, 1991). The same was done for apple, which had its solid soluble contents increased (Visai et al., 1989), but not presenting alterations regarding the sugar contents (Wang and Steffens, 1987).

The 'Smooth Cayenne', which is, despite of its acidity, most internationally commercialized compounds the largest part of the desired characteristics for the export (yellow pulp, cylindrical shape, small crow, soluble solids among 13 and $14^{\circ}$ Brix).

This work aimed to assess the alterations of physico-chemical characteristics of the pineapple fruit of variety 'Smooth Cayenne'. The assessment consisted of comparison of the commercialization standards as well the variations caused by the harvesting period, using the paclobutrazol plant growth regulator intending to harvest the fruits in a period of low demand of this product in the market.

\section{MATERIAL AND METHODS}

The assay was performed at the municipality of Presidente Alves - SP, Brazil (22006'66" S, 49 $26^{\prime} 17^{\prime \prime}$ W) from May 2002 to February 2004. The reason for choosing this area was due to the favourable climatic conditions to the culture of pineapple, and the concentration of a large pineapple production. The cultivar used was the Smooth Cayenne, the predominant cultivar in this region and the most world-widely cultivated one due to its quality and commercial acceptance. There were slips weighing $300 \mathrm{~g}$, planted in double lines of $1.00 \times 0.50 \times 0.30 \mathrm{~m}$. The management of the production was performed according to Raij et al. (1997). The product used was the paclobutrazol at 100,150 and $200 \mathrm{mg} \mathrm{L}^{-1}$, applied 2, 3 or 4 times, (Table 1) in pineapple plants of 11 months of age planted in May 2002.

Table 1 - Treatment and application period of paclobutrazol (2003).

\begin{tabular}{|c|c|c|c|c|}
\hline Treatments & $\begin{array}{c}\text { APRIL } \\
\mathbf{1}^{\text {st }} \text { fortnight } \\
\text { PBZ }^{*}\left(\mathrm{mg} \mathrm{L}^{-1}\right)\end{array}$ & $\begin{array}{c}\text { APRIL } \\
2^{\text {nd }} \text { fortnight PBZ* } \\
\left(\mathrm{mg} \mathrm{L}^{-1}\right)\end{array}$ & 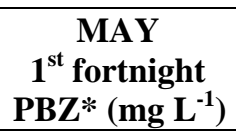 & $\begin{array}{c}\text { MAY } \\
2^{\text {nd }} \text { fortnight } \\
\text { PBZ }^{*}\left(\text { mg L }^{-1}\right) \\
\end{array}$ \\
\hline 1 & 100 & 100 & 100 & 100 \\
\hline 2 & 150 & 150 & 150 & 150 \\
\hline 3 & 100 & 100 & 100 & - \\
\hline 4 & 150 & 150 & 150 & - \\
\hline 5 & - & 100 & 100 & - \\
\hline 6 & - & 150 & 150 & - \\
\hline 7 & 200 & 200 & 200 & 200 \\
\hline 8 & 200 & 200 & 200 & - \\
\hline 9 & - & 200 & 200 & - \\
\hline 10 (control) & water & water & water & water \\
\hline
\end{tabular}


The plant growth regulator solutions were sprayed on the whole plant $(50 \mathrm{~mL})$ with a back sprayer, concentrated mainly on the center of the leaf rosette. The treatment included the non-ionic surfactant alkil-phenol-poliglico-ether (Extravon) at $0.05 \%$. The experiment was performed under completely randomized block design, totalizing 10 treatments, three repetitions with fortnight product application that started in April and finished in May (Table 1).The plants that did not present a visible inflorescences until 15/08/03 were artificially induced through the pulverization of (2-chloroethyl) phosphonic acid or ethephon, commercially known as Ethrel, containing $240 \mathrm{~g} \mathrm{~L}$ ${ }^{1}$ of ethephon $(200 \mathrm{~mL}$ of ethrel/100L of water +2 $\mathrm{kg}$ of urea). The plots of each treatment were constituted of 40 plants placed in double lines of 20 plants each, totalizing 30 plots and 1200 plants. The assessments regarding the flowering inhibition were done weekly from July 10 to August 9, 2003. The fruit harvesting started in the second fortnight of December 2003 and finished in the second fortnight of February 2004. Over all three fruits aleatory were harvested at the internal lines of the plots when the fruits were in the maturation stage "with dots", which was characterized by the presentation of little fruits with yellow centres (Programa Brasileiro para Modernização da Horticultura, 2003).

The fruits without disease symptoms, lesions, injuries, burns, crumpled, fasciations, and the soluble solid content above $12^{\circ}$ Brix were considered as commercial. For the analysis of the physico-chemical characteristics were considerate as the followings: average diameter of the fruit using the Mitutoyo digital paquimeter; fruit and crown lengths determined with paquimeter and dry matter of the crown and fruits utilizing digital electrical scale with $0.01 \mathrm{~g}$ precision; titration acidity (AT) was determined through the titration of the pineapple pulp juice with sodium hydroxide $(0.1 \mathrm{~N})$. Results were expressed in gram of citric acid $100 \mathrm{~g}^{-1}$ pulp. Because it is a fruit with sequential development in spiral, from the bottom to the top (Reinhardt et al., 2004), the samples of each fruit were combined of $1 / 4$ of the fruit in the longitudinal sense, covering portions of the basal, median and apical regions of the fruit (Programa Brasileiro para Modernização da Horticultura, 2003). This portion was triturated, filtered and an aliquot was taken for the chemical determinations. The $\mathrm{pH}$ was measured in the same aqueous extract in potentiometer; the soluble solid contents ( $\left.{ }^{\circ} \mathrm{Brix}\right)$ using Attago digital refractometer and the total and reducer sugars were determined by the technique of Somogy, adapted by Nelson (1944).The data were submitted to the variance analysis ( $F$ test) with comparison of average by the Tukey test at $5 \%$ of probability.

\section{RESULTS AND DISCUSSION}

The results were compared to values of the normal standards of commercialization to verify the fruit quality and assess the possible dependent variations of the treatment used in the experiment.

\section{Physico-chemical characteristics:}

There were variations in some physico characteristics of the fruit of pineapple plant in relation of the treatment with paclobutrazol aiming to inhibit the floral differentiation process of the pineapple plant (Table 2).

For the fresh matter, significative differences occurred among the treatments. The treatment with paclobutrazol at $200 \mathrm{mg} \mathrm{L}^{-1}$ applied four times, that is, the highest concentration and application frequency, showed the best fresh matter of pineapple fruits in relation to the control, which presented the highest values showing that high concentrations might offer unfavourable results on the fresh matter of the fruits. In general, the period of regular offer of the fruits, the market prefers fruits with average fresh matter superior to $1.5 \mathrm{~kg}$. However, the market commercializes fruit weight from $0.9 \mathrm{~kg}$ (fruits belonging to the class I) to $2.4 \mathrm{~kg}$ (classe VI, Programa Brasileiro para Modernização da Horticultura, 2003) depending on the market niche to which they are destined. The fruit length presented differences among the treatments. The fruits from the treatment with paclobutrazol $150 \mathrm{mg} \mathrm{L}^{-1}$ applied four times presented the smallest lengths, while the control presented the highest fruit length and smallest crown length. Regarding the fruit diameter and crown fresh matter, there was no significative alterations among the treatments.

Barbosa (1997) obtained differences among the treatments with urea and plant growth regulators for cv. Pérola (pearl) where the smallest values obtained for fresh matter and crown length were observed in the control treatments, paclobutrazol, and urea, respectively. In relation to the fresh 
matter, the control presented the best result, followed by the urea treatment, and paclobutrazol treatment, similar to the length obtained in this study. The average values obtained for the crown fresh matter was $111 \mathrm{~g}$ and for the crown length was $19.7 \mathrm{~cm}$. The fresh matter (without the crown) was $1.17 \mathrm{~kg}$ and the length was $20.5 \mathrm{~cm}$, wich was the normal standard of this cultivar.

Table 2 - Fruit fresh matter $(\mathrm{g})$, average diameter $(\mathrm{cm})$, pineapple fruit length $(\mathrm{cm})$ and length $(\mathrm{cm})$ and fresh matter of the crown $(\mathrm{g})$ treated with paclobutrazol.

\begin{tabular}{|c|c|c|c|c|c|}
\hline Treatments & $\begin{array}{l}\text { Fresh } \\
\text { matter(Fruit) }\end{array}$ & $\begin{array}{l}\text { Average } \\
\text { diameter } \\
\text { (Fruit) }\end{array}$ & $\begin{array}{l}\text { Lengh } \\
\text { (Fruit) }\end{array}$ & $\begin{array}{l}\text { Lengh } \\
\text { (Crown) }\end{array}$ & $\begin{array}{l}\text { Fresh } \\
\text { Matter } \\
\text { (Crown) }\end{array}$ \\
\hline $1-100 \mathrm{mg} \mathrm{L}^{-1}$ (4 times) & $1604.20 \mathrm{abcd}$ & $11.30 \mathrm{a}$ & $16.67 \mathrm{bc}$ & $18.33 \mathrm{a}$ & $231.60 \mathrm{a}$ \\
\hline 2- $150 \mathrm{mg} \mathrm{L}^{-1}$ (4 times) & $1366.79 \mathrm{~cd}$ & $11.19 \mathrm{a}$ & $14.57 \mathrm{c}$ & $20.23 \mathrm{a}$ & $187.68 \mathrm{a}$ \\
\hline 3- $100 \mathrm{mg} \mathrm{L}^{-1}$ (3 times) & $1654.69 \mathrm{abc}$ & $11.42 \mathrm{a}$ & $17.33 \mathrm{~b}$ & $18.23 \mathrm{a}$ & $186.05 \mathrm{a}$ \\
\hline 4- $150 \mathrm{mg} \mathrm{L}^{-1}$ (3 times) & $1643.43 \mathrm{abc}$ & $11.40 \mathrm{a}$ & $17.00 \mathrm{~b}$ & $18.10 \mathrm{a}$ & $198.92 \mathrm{a}$ \\
\hline 5- $100 \mathrm{mg} \mathrm{L}^{-1}(2$ times $)$ & $1741.00 \mathrm{ab}$ & $11.62 \mathrm{a}$ & $17.30 \mathrm{~b}$ & $18.33 \mathrm{a}$ & $205.51 \mathrm{a}$ \\
\hline 6- $150 \mathrm{mg} \mathrm{L}^{-1}$ (2 times) & $1609.31 \mathrm{abcd}$ & $11.48 \mathrm{a}$ & $16.10 \mathrm{bc}$ & $18.70 \mathrm{a}$ & $225.58 \mathrm{a}$ \\
\hline 7- $200 \mathrm{mg} \mathrm{L}^{-1}$ (4 times) & $1310.51 \mathrm{~d}$ & $10.94 \mathrm{a}$ & $15.03 \mathrm{bc}$ & $18.10 \mathrm{a}$ & $180.72 \mathrm{a}$ \\
\hline 8- $200 \mathrm{mg} \mathrm{L}^{-1}$ (3 times) & $1488.93 \mathrm{bcd}$ & $11.21 \mathrm{a}$ & $16.10 \mathrm{bc}$ & $17.33 \mathrm{ab}$ & $155.41 \mathrm{a}$ \\
\hline 9- $200 \mathrm{mg} \mathrm{L}^{-1}$ (2 times) & $1574.58 \mathrm{abcd}$ & $11.37 \mathrm{a}$ & $16.57 \mathrm{bc}$ & $18.80 \mathrm{a}$ & $191.85 \mathrm{a}$ \\
\hline 10- Control & $1857.28 \mathrm{a}$ & $11.27 \mathrm{a}$ & $20.10 \mathrm{a}$ & $14.23 \mathrm{~b}$ & $124.44 \mathrm{a}$ \\
\hline C.V.\% & 6.50 & 2.13 & 4.73 & 6.35 & 21.32 \\
\hline
\end{tabular}

Averages (means) followed by the same letter do not significantly difference among themselves, through Tukey test at $5 \%$ of probability.

Cunha et al. (2002) in their study obtained cv. Pérola (pearl) fruits heavier in plants treated with 2-(3-chlorophenoxy) propionic acid (CPPA) $(1.119 \mathrm{~g})$ and the lighter fruits in those treated with paclobutrazol $(940 \mathrm{~g})$, being the control $1.013 \mathrm{~g}$ when applied in May/Jun. These results were similar to the ones found in this work. Concerning the April/May assay, no significative differences among were observed the treatments (CPA, paclobutrazol, tebuconazole, propaconazole, and control), which were referent to the fresh matter of the fruit with the crown and performance of fruits per hectare. Some authors have obtained increase of the fresh matter for different fruit species with paclobutrazol application (Smeirat and Quenfleh, 1989; Kurian and Iyer, 1993) and others reduction (Steffens et al., 1993).

The Smooth Cayenne cultivar is characterized by fruits weighing between 1.300 and $2.500 \mathrm{~g}$, length ranging from 14.6 to $19.0 \mathrm{~cm}$, diameter from 11.1 to $14.0 \mathrm{~cm}$ (Gonçalves and Carvalho, 2000; Manica, 2000), average crown fresh matter of $248.4 \mathrm{~g}$ and average crown length of $16.55 \mathrm{~cm}$ (Bleinroth, 1987). Therefore, even occurring some significative differences among the treatments in parameters related to the pineapple fruit physic characteristics, they are maintained within the fruit quality standards for their commercialization. For
Smooth Cayenne cultivar, the majority of the commercialized fruits ranged from 1.5 to $2.1 \mathrm{~kg}$ (Almeida et al., 2004).

On maturation, the fruit is completely developed and reaches the maximum esthetic and the comestible quality. In this phase, there is an accentuated addition of soluble solid contents, an increase in the reducing sugars and sucrose contents confering to the fruit the sweet flavour, an increase in the volatile compounds linked to the aroma, and the increase of the acid content in the beginning and a decrease afterwards (Gonçalves and Carvalho, 2000).

Table 3, showed that the chemical characteristics of the pineapple fruits were not altered. Significative differences was found in any of the variables among the treatments in relation to the control. The values found for the tritable acidity contents (from 0.49 to $0.58 \mathrm{~g}$ of citric acid $100 \mathrm{~g}^{-1}$ pulp) and $\mathrm{pH}$ (from 3.8 to 3.9 ), according to the Table 4, agreed with the ones found for the same cultivar by Manica (2000) that were the followings: from 0.31 to $0.84 \mathrm{~g}$ citric acid $100 \mathrm{~g}^{-1}$ pulp and 2.9 to 3.9 , respectively. Reinhardt and Medina (1992) found smaller values for tritable acidity, from 0.61 to $0.65 \mathrm{~g}$ of citric acid $100 \mathrm{~g}^{-1}$ of pulp. 
Table 3 - Tritable acidity (AT) (g of citric acid $100 \mathrm{~g}^{-1}$ of pulp), $\mathrm{pH}$, soluble solid (SS) ( ${ }^{\circ} \mathrm{Brix}$ ), total and reducing sugars (\%) of pineapple fruits treated with paclobutrazol.

\begin{tabular}{llllcc}
\hline Treatments & AT & pH & SS & Total sugars & $\begin{array}{c}\text { Reducing } \\
\text { sugars }\end{array}$ \\
\hline $1-100 \mathrm{mg} \mathrm{L}^{-1}$ (4 times) & $0.581^{*}$ & $3.92^{*}$ & $14.93^{*}$ & $14.63^{*}$ & $4.37^{*}$ \\
$2-150 \mathrm{mg} \mathrm{L}^{-1}$ (4 times) & 0.495 & 3.95 & 15.17 & 14.92 & 4.17 \\
$3-100 \mathrm{mg} \mathrm{L}^{-1}$ (3 times) & 0.495 & 3.98 & 14.83 & 14.35 & 4.64 \\
$4-150 \mathrm{mg} \mathrm{L}^{-1}$ (3 times) & 0.529 & 3.94 & 15.47 & 15.17 & 4.36 \\
$5-100 \mathrm{mg} \mathrm{L}^{-1}$ (2 times) & 0.512 & 3.96 & 15.43 & 14.74 & 4.26 \\
6- $150 \mathrm{mg} \mathrm{L}^{-1}$ (2 times) & 0.542 & 3.86 & 15.13 & 14.09 & 4.19 \\
7- $200 \mathrm{mg} \mathrm{L}^{-1}$ (4 times) & 0.549 & 3.88 & 14.30 & 14.30 & 4.61 \\
8- $200 \mathrm{mg} \mathrm{L}^{-1}$ (3 times) & 0.561 & 3.83 & 14.43 & 13.68 & 4.06 \\
9- $200 \mathrm{mg} \mathrm{L}^{-1}$ (2 times) & 0.513 & 3.90 & 13.80 & 13.68 & 4.21 \\
10- Control & 0.518 & 3.95 & 13.53 & 13.26 & 4.05 \\
\hline C.V.\% & 10.59 & 2.62 & 5.68 & 6.30 & 7.90 \\
\hline Averges
\end{tabular}

Averages (means) do not significantly difference among themselves, through $\mathrm{F}$ test.

The Ministry of Agriculture, Cattle Raising and Supply [Ministério da Agricultura, Pecuária e Abastecimento (MAPA)] of Brazil has regularized through decree, in 2002, the classification and standards of commercialization of pineapple fruit to whole national territory including specific qualitative exigencies such as minimal content of soluble solid corresponding to $12^{\circ}$ Brix (Programa Brasileiro para Modernização da Horticultura, 2003). Therefore, the results found for soluble solid contents (from 13.5 to $15.4^{\circ}$ Brix) are within the desired standards for the commercialization and coherent to the ones found by Manica (2000), 10.9 to $18.8^{\circ}$ Brix. Reinhardt and Medina (1992) found for the Smooth Cayenne cultivar soluble solid contents from 13.3 to $13.5^{\circ}$ Brix and Kist et al. (1991) from 13.31 to $14^{\circ}$ Brix without any significant influence in any treatment. Barbosa (1997) studying the flowering control and using paclobutrazol found soluble solid contents of $12.87^{\circ}$ Brix, for the Pérola cultivar, without any significant difference in relation to the control. Facteau and Chestnut (1991), utilizing paclobutrazol did not find difference regarding the soluble solid of cherries as well.

The pineapple fruit characteristic flavour and aroma are determined according to the sugars and organic acids contents among others. With regard to the sugars present in the pineapple, sucrose contributed with $66 \%$ of the sugars and the $34 \%$ remaining were represented by the reducing sugars, glucose and fructose (Bleinroth, 1987).

According to Coelho and Cunha (1982), soluble solids in the pineapple fruit comprised sugars, specially $(85 \%)$, in the form of sucrose.
Table 3 also presents the results on the total and reducing sugars. In relation to the control (treatment 10), which received only water, the other treatments did not present significant statistical difference to these variables. Medina et al. (1987) described for 'Smooth Cayenne' pineapple, soluble solid contents of $18.2^{\circ}$ Brix, $16.17 \%$ of total sugars and $5.35 \%$ for reducing sugars, close to the contents found in this work, highlighting that these values might vary in function to the edaphoclimatic conditions, fertilization, planting time, and harvest.

Chitarra and Chitarra (1990) describe values of $13.5 \%$ to total sugars in pineapple fruit, agreeing with the values obtained in this work and behaviour similar to the one obtained by Botrel et al. (2002) that have presented total sugar values of $14.55 \%$ for healthy fruit of Pearl cultivar, despite this cultivar present smaller contents of sugars in relation to Smooth Cayenne cultivar.

As there was no data in the literature regarding the paclobutrazol influence on the total and reducing sugars in pineapple fruit, this proposition might be the initial point for further studies.

In general, the application of plant growth regulator (paclobutrazol) did not interfered in the studied chemical characteristics for the pineapple fruit.

\section{Harvest time:}

Several treatments with paclobutrazol altered the harvest period of the fruits in several concentrations and application periods (Table 4). In relation to the control, all the treatments had inhibiting effect on the natural floral 
differentiation contributing, therefore, to the extension of the harvest period for the period when the fruits reached the highest price. This result agreed with are same with Morgado et al. (2004) who registed November and December as the months of lowest price for the pineapple fruits due to the harvest concentration in this period, which required further studies.

The treatment with $150 \mathrm{mg} \mathrm{L}^{-1}$ (4 times); $150 \mathrm{mg}$ $\mathrm{L}^{-1}$ (twice); $200 \mathrm{mg} \mathrm{L}^{-1}$ (4 times) and $200 \mathrm{mg} \mathrm{L}^{-1}$ (3 times) of paclobutrazol considerably delayed the harvest period in relation to the other treatments (Table 4), allowing the harvest in the first and second fortnight of February, when the prices of the fruit were more expensive. Among these treatments, paclobutrazol at $150 \mathrm{mg} \mathrm{L}^{-1}$ (twice) produced the fruits with the highest fresh matter in relation to the other treatments in the same harvest period.

Cunha et al. (2002) using several plant growth regulator observed that paclobutrazol contributed to the expansion of period and delayed the harvest of pineapple fruit, corroborating with the results obtained in this work. Min (1995) cited by Cunha et al. (2002) reported that the 2- (3clorofenoxiphenoxy) propionic acid and paclobutrazol, in slower concentrations, delayed the flowering around 20 - 40 days in relation to the control, while with higher concentration, they were maintained in the vegetative stage. In relation to the fruit fresh matter, Barbosa (1997) and Cunha et al. (2002) achieved a delay in the harvest period using paclobutrazol, although the fruits were with lower fresh matter compared to this work.

The results showed that paclobutrazol did not alter the chemical characteristics of the fruits and maintained the other characteristics equivalent to the commercial standards. It also reduced the harvest period. Thus, the results are of great relevance to commercial applications.

\section{CONCLUSIONS}

-None of the treatments using paclobutrazol altered the chemical characteristics of the 'Smooth Cayenne' pineapple;

-Even having the influence of treatments in the fresh matter and length of the fruits, these were maintained under the quality standards for commercialization;

-Paclobutrazol at $150 \mathrm{mg} \mathrm{\textrm {L } ^ { - 1 }}$ applied twice presented the best results collectively in relation to the harvest delay and fruit fresh matter.

Table 4- Paclobutrazol influence in the harvest period of pineapple fruit and fruit fresh matter (g), 2003/2004.

\begin{tabular}{|c|c|c|c|c|c|}
\hline \multirow[t]{3}{*}{ Treatments } & DeceI & $\mathrm{r} / 2003$ & January/ 2004 & February/ 2004 & \multirow{3}{*}{ Fruit fresh matter $(\mathrm{g})$} \\
\hline & \multicolumn{2}{|c|}{ Fortnight } & Fortnight & Fortnight & \\
\hline & $1^{\mathrm{st}}$ & $2^{\text {nd }}$ & $1^{\text {st }} \quad 2^{\text {nd }}$ & $1^{\text {st }} 2^{\text {nd }}$ & \\
\hline $100 \mathrm{mg} \mathrm{L}^{-1}(4 \text { times })^{3}$ & & & & & $1604.2 \mathrm{abcd}$ \\
\hline $150 \mathrm{mg} \mathrm{L}^{-1}$ (4 times) & & & & & $1366.8 \mathrm{~cd}$ \\
\hline $100 \mathrm{mg} \mathrm{L}^{-1}(3 \text { times })^{2}$ & & & & & $1654.7 \mathrm{abc}$ \\
\hline $150 \mathrm{mg} \mathrm{L}^{-1}(3$ times $)$ & & & & & $1643.4 \mathrm{acb}$ \\
\hline $100 \mathrm{mg} \mathrm{L}^{-1}(2 \text { rimes })^{1}$ & & & & & $1741.0 \mathrm{ab}$ \\
\hline $150 \mathrm{mg} \mathrm{L}^{-1}(2$ times $)$ & & & & & 1609.3abcd \\
\hline $200 \mathrm{mg} \mathrm{L}^{-1}$ (4 times) & & & & & $1310.5 \mathrm{~d}$ \\
\hline $200 \mathrm{mg} \mathrm{L}^{-1}$ (3 times) & & & & & $1488.9 \mathrm{bcd}$ \\
\hline $200 \mathrm{mg} \mathrm{L}^{-1}(2$ times $)$ & & & & & 1574.6abcd \\
\hline Control & & & & & $1857.3 \mathrm{a}$ \\
\hline C.V.(\%) & & & & & 6.50 \\
\hline
\end{tabular}

Averages (means) followed by the same letter do not significantly difference among themselves, through Tukey test at $5 \%$ of probability.

\footnotetext{
${ }^{(1)}$ Application of paclobutrazol in the second fortnight of April and first fortnight of May 2003.

${ }^{(2)}$ Application of paclobutrazol in the first and second fortnights of April and first fortnight of May 2003.

(3) Application of paclobutrazol in the first and second fortnights of April and first and second fortnights of May 2003.
} 


\section{RESUMO}

O objetivo deste trabalho foi avaliar o efeito de um inibidor da diferenciação floral nas características físico-químicas dos frutos do abacaxizeiro, bem como, no período de colheita. Utilizou-se paclobutrazol a 100,150 e $200 \mathrm{mg} \mathrm{L}^{-1}$ aplicados 2, 3 ou 4 vezes, em plantas de abacaxi cv. Smooth Cayenne. Os tratamentos não influenciaram nas características químicas dos frutos, e mesmo alterando algumas características físicas, os frutos permaneceram dentro dos padrões de qualidade para comercialização. O período de colheita foi ampliado em todos os tratamentos comparando-se com o controle, porém, $150 \mathrm{mg} \mathrm{L}^{-1}$ aplicados 2 vezes promoveu melhor resultado analisando-se em conjunto a época de colheita com a massa fresca do fruto.

\section{REFERENCES}

Agrianual (2004), Anuário da agricultura brasileira. FNP Consultoria and Comércio, São Paulo.

Almeida, C.O.; Vilar, L.C.; Souza, F.S.; Reinhardt, D.H. Macedo, C.M. (2004), Peso médio do abacaxi no Brasil: um tema em discussão. Disponível em: $<$ http://www.todafruta.com.br/htm. $>$.Acesso em: 30 nov. 2004.

Barbosa, N.M.L. (1997), Efeito de reguladores e da adubação nitrogenada no controle do florescimento natural precoce do abacaxizeiro. 1997. 59p. Dissertação , Universidade Estadual da Bahia, Cruz das Almas, Bahia.

Barbosa, N.M.L.; Cunha, G.A.P.; Reinhardt, P.G.B. (1998), Controle da floração natural do abacaxizeiro "Pérola" com uréia e reguladores de crescimento no Recôncavo Baiano. Rev. Bras. Frutic., 20, 359-366.

Bleinroth, E.W. (1987), Matéria prima. In: ITAL. Abacaxi: cultura, matéria prima, processamento e aspectos econômicos. 2.ed., ITAL, Campinas, pp. 133-164. (série Frutas Tropicais, 2).

Botrel, N.; Carvalho, V.D.; Oliveira, E.F.; Soares, A.G.; Cenci, S.A. (2002), Efeito da 'mancha chocolate' nas características físico-químicas e químicas de frutos de abacaxizeiro-'Pérola”. Rev. Bras. Frutic., 24, 77-81.

Chitarra, M.I.F.; Chitarra, A.B. (1990), Pós-colheita de frutos $e$ hortaliças: fisiologia e manuseio. UFLA/FAEPE, Lavras.
Coelho, Y.S.; Cunha, G.A.P. (1982), Critérios de avaliação da maturação e qualidade de frutos, com ênfase para citros e abacaxi. EMBRAPA/CNPMF, Cruz das Almas, 1982.20p. (Circular Técnico,1).

Cunha, G.A.P.; Costa, J. T.A.; Reinhardt, D.H. (2002), Alterações na massa foliar, produção de mudas, rendimento e colheita do abacaxizeiro 'Pérola'causadas por reguladores de crescimento. Paper presented at $17^{\text {th }}$ Congresso Brasileiro de Fisiologia, Belém. Disponível em: <http://www.ufpel.tche.br/sbfruti/anais_xvii_cbf/fisio logia/186.htm >.Acesso em: 07 jan. 2004.

Cunha, G.A. P.; Costa, J.T.A.; Reinhardt, D.H. (2003), Natural flowering in pineapple: inhibition by growth regulators. Fruits, 58, 27-37.

Davies, T.D.; Steffens, G.L. Sankhla, N. (1998), Triazole plant growth regulators. Horticult. Rev., 10, 63-105.

Facteau, T.J.; Hestnut, N.E. (1991), Growth, fruiting, flowering, and fruit quality of sweet cherries treated with paclobutrazol. Hortscience, 26, 276-278.

Gonçalves, N.B.; Carvalho, V.D. (2000), Características da fruta. In: Abacaxi pós-colheita, Abreu, C.M.P.; Amaral, C.M.; Reinhardt, D.H.R.C. Embrapa, Brasília,13-27,(Frutas do Brasil, 5).

Kist, H.G.K.; Manica,I.; Gama, F.S.N.; Accorsi, M.R. (1991), Influência do plantio do abacaxi cv. Smooth Cayenne. Pesqui. Agropecu. Bras., 26, 325-330.

Kurian, R.M.; Iyer, C.P.A. (1993), Chemical regulation of tree size in mango (Mangifera indica L.) $\mathrm{cv}$. Alphonso II. Effects of growth retardants on flowering and fruit set. J. Hortic. Sci., 68, 355-360.

Manica, I. (2000), Abacaxi: do plantio ao mercado. Cinco Continentes, Porto Alegre.

Medina, J.C.; Bleinroth, E.W.; Martin, Z.J.; Tocchini, R.P.; Soler, M.P. (1987), Abacaxi: Cultura, materiaprima, processamento e aspectos econômicos. ITAL, Campinas.

Min, X.J.; Bartholomew, D.P. (1996), Effect of plant growth regulators on ethylene production, 1aminocyclopropane-1-carboxilic acid oxidase activity, and initiation of inflorescence development of pineapple. J. Plant Growth Regul., 15, 121-128.

Morgado, I.F. Aquino, C.N.; Terra, T.C. (2004), Aspectos econômicos da cultura do abacaxi: sazonalidade de preços no Estado do Rio de Janeiro. Rev. Bras. Frutic., 26, 44-47.

Nelson, N.A. (1944) A photometric adaptation of Somogy method for the determination of glucose. $J$. Biological Chemistry, 135, 136-175.

Programa Brasileiro para a Modernização da Horticultura. (2003), Normas de classificação do abacaxi. Centro de Qualidade em horticultura CQH/CEAGESP, São Paulo, ( CQH - Documentos, 24).

Py, C.; Lacoeuilhe, J.; Teisson, C. (1984), L'ananas: as culture, sés produits. Maissonneuve, Paris. 
Raij, B.V.; Cantarella, H.; Quaggio, J.A. et al. (1997), Recomendações de adubação e calagem para o Estado de São Paulo. São Paulo, Campinas: Instituto Agronômico and Fundação IAC. (Boletim Técnico; 100).

Reinhardt, D.H.R.C.; Medina, V.M. (1992), Crescimento e qualidade do fruto do abacaxi cvs. Pérola e Smooth Cayenne. Pesqui. Agropecu. Bras., 27, 435-447.

Reinhardt, D.H.R.C.; Medina, V.M.; Caldas, R.C.; Cunha, G.A.P.; Estevam, R.F.H. (2004), Gradientes de qualidade em abacaxi 'Pérola' em função do tamanho e do estádio de maturação do fruto. Rev. Bras.Frutic., Jaboticabal, 26, 544-546.

Sampaio, A.C.; Araújo, J.A.C.; Ruggiero, C.; Salgado, H.M.(1992), Variação estacional de preços do abacaxi no mercado atacadista de São Paulo. Rev. Bras. Frutic.,14, 19-24.
Smeirat, N.; Quenfleh, M.(1989), Effect of paclobutrazol on vegetative and reprodutive growth of 'Lisbon'lemon. Acta Hortic., 239, 261-264.

Steffens, G.L.; Jacobs, F.W.; Engelhaup, M.E. (1993), Size, flowering and fruiting of maturing own rooted 'Gala'apple trees treated with paclobutrazol apray and trunk drenches. Sci. Hortic., 56, 13-21.

Visai, C. Faila, O. Eccher, T. (1989), Effect of promalin and paclobutrazol on cracking and quality of Neipling Stayman apples. Acta Hortic., 239, 451-454.

Wang, S.Y. Steffens, G.L. (1987), Postharvest response of 'Spartan' apples to preharvest paclobutrazol treatment. Hortic.Sci.,22, 276-278.

Received: December 23, 2005; Revised: June 29, 2006; Accepted: March 29, 2007. 